\title{
The Politics of Standard English: An Exploration of Thai Tertiary English Learners' Perceptions of the Notion of Standard English
}

\author{
Naratip Jindapitak ${ }^{1}$ \\ ${ }^{1}$ Department of Languages and Linguistics, Faculty of Liberal Arts, Prince of Songkla University, Hatyai \\ Campus, Thailand \\ Correspondence: Naratip Jindapitak, Department of Languages and Linguistics, Faculty of Liberal Arts, Prince \\ of Songkla University, Hatyai Campus, 90110, Thailand. E-mail: royalsharp@gmail.com
}

Received: February 5, 2013 Accepted: March 7, 2013 Online Published: April 27, 2013

doi:10.5539/ass.v9n5p118 URL: http://dx.doi.org/10.5539/ass.v9n5p118

\begin{abstract}
Given that English becomes a lingua franca in the world in which more and more non-native speakers use it to suit their own purposes in local contexts, the ownership of English becomes denationalized. English as an international language scholars have maintained that English learners do not need to approximate the norms of native speakers as closely as possible. Hence, pedagogical attempts based on native-speaker linguistic standards become irrelevant in the contexts where English is mainly used as a lingua franca to serve such wider communicative purposes. In this study, I investigated how the notion of standard English was construed by the Thai tertiary English majors. Focus group interview was used as a research tool to obtain participants' critical perceptions. The results revealed that although the participants expressed that the notion of standard English was a complex issue that requires careful interpretation, deeply inside, it was still anchored to the ideology of native speaker or at least had to include the construct of native speaker in its working definition. Maintaining that the notion of standard English is a political construct rather than a linguistic reality, the paper ends by suggesting some pedagogical ideas that aim at raising learners' awareness of the global role of English.
\end{abstract}

Keywords: standard English, English as an international language, English as a lingua franca, world Englishes, native speaker ideology

\section{Introduction and Contextualization}

It is unquestionable that English functions as an international language (EIL) in the globalized world. Kachru (1992) considers the concept of EIL as the present state of English that is used as a global language for wider communication. In other words, English is considered as the world's lingua franca which is most utilized to serve both intra- and international communication. Additionally, McKay (2002) illustrates that the functions of EIL can be in both global and local sense. In a global sense, it is used as an international lingua franca between speakers from different mother tongue backgrounds. In a local sense, it is used as a communicative tool to cater meaningful interactions between local speakers within one country.

To acknowledge the phenomenal spread of English in the world, Kachru's (1992) classical model of the concentric circles of English use needs to be brought to light. Kachru (1992) describes the way English is used in the world in the form of three concentric circles: The Inner Circle, Outer Circle and Expanding Circle. The "Inner Circle" refers to native- speaking countries (e.g., USA, UK, Canada, Australia, New Zealand, Ireland, etc.) where English is used as a mother tongue or as a first language. The use of English in this circle is reflected in every sphere of life. Simply put, people in this circle extensively use English as a means to cater every communicative confrontation. The "Outer Circle" refers to former colonial countries (e.g., The Philippines, India, Singapore, Malaysia, Ghana, Nigeria, etc.) where English is used as a second or institutionalized language. People in this circle use English alongside their mother tongue for official or institutionalized interactions. As many outer-circle English varieties have the history of the colonial past and have institutionalized role within local contexts, they are often called nativized, institutionalized or indigenized Englishes. The last circle is called the "Expanding Circle" which refers to such countries as Thailand, China, Japan, Germany and France, where English is used as a foreign or an additional language. Even though English in this circle does not share the sense of colonization and has no official role in daily-life interactions, it is given special priority as an important foreign language that is dominant in several domains of life (e.g., business and commerce, higher 
education, media, science and technology).

What we can learn from Kachru's classifications of English is that English is not exclusively used to serve only native speakers' daily communicative purposes. In fact, English is used more by non-native speakers in the Outer and Expanding Circle. Crystal (2003) notes that when English is used outside the Inner Circle, it is exclusively adapted to "cultural mindsets of the people who have chosen to use it" (p. 23). As a result, English has come to be mingled with indigenous or local conventions of the countries in which it is used. To illustrate, English has developed new conventions of thought, customs, codes of practice (Widdowson, 1994) and standards in their own rights (Crystal, 2000; Kirkpatrick, 2007; Jenkins, 2000; Seidlhofer, 2006).

It should be noted that since English today has metamorphosed into several new international and local Englishes, the question as to what English varieties should be adopted as standards for English language teaching (ELT) in non-native settings has become a hot topic of discussion in several academic contexts. Acar (2007) supports that with the development of new Englishes in non-mother tongue contexts, the current discussions have begun to address the issues of standard English in relation to English language learning and teaching. Unlike other indigenous languages (e.g., Thai, Korean, Vietnamese, Swedish and Danish) in which they are learned and used to interact with their native speakers in a limited range of contexts, English is used not only to interact with native speakers but also with non-native speakers who are the majority of English users in the world. In addition, Prodromou (1997) claims that an estimated 80 per cent of meaningful communication in English takes place between non-native speakers. Kirkpatrick (2007) even observes that in China alone, there are more English language learners than the populations of the inner-circle countries combined.

It is clear that English has shifted from being a language that was traditionally used in particular native-speaking nations to serving as a wider communicative medium for innumerable organizations and individuals around the world. Given that English has come to be spoken by billions of international speakers in non-native settings, it has ceased to be the sole property of people with particular ethnic backgrounds or tied up with particular inner-circle communities (Widdowson, 1994, 1997). Thus, the deeply rooted ELT assumption claiming that 'standard English', the model that language learners should aspire for, should be informed by native speakers (Buripakdi, 2012a, 2012b; Jindapitak \& Teo, 2011, 2012) seems to be less supported and unrealistic. This is because we now live in the globalized era where people speak Englishes rather than English, those using the language in order to communicate with international speakers. Tupas (2006) articulates that the shift of power from inner-circle speakers to outer- and expanding-circle speakers "may have legitimized different cultures and local uses of English around the world" (p. 169). Viewing the language through the lens of linguistic decentralization, Widdowson (1994) excellently puts it: "You are proficient in a language to the extent that you possess it, make it your own, bend it to your will, assert yourself through it rather than simply submit to the dictates of its form" (p. 384). In line with Widdowson's critical stance of English as a lingua franca and the issue of ownership in language proficiency, Achebe (1975), an African novelist, additionally reflects on the relationship between language and local adaptation. He illustrates that: “. . . the English language will be able to carry the weight of my African experience ... But it will have to be a new English, still in communion with its ancestral home but altered to suit its new African surroundings" (Achebe, 1975, p. 62).

The above quotes generate the idea that legitimizing a certain inner-circle variety as standard and marginalizing non-mainstream Englishes by means of native-speaker linguistic prescription alone is unempirical, idiosyncratic and undemocratic. In fact, several EIL scholars (e.g., Cook, 2001; Holliday, 2008; Jenkins, 2000, 2006, 2007; Kachru, 1992; Kirkpatrick, 2007; Matsuda, 2003; McKay, 2002, 2003; Seidlhofer, 2001; Tupas, 2006; Widdowson, 1994, 1997, 1998) have maintained that the term 'standard English' needs to be redefined and re-evaluated by taking into account the sociolinguistic and sociocultural dimensions of English. Hence, it is necessary to problematize the notion of standard English in ELT in the periphery. Without critical problematization of such issues, English learners or users may end up forming the idea of resistance when they are in contact with English speakers who speak Englishes or use various non-native norms (Matsuda, 2003). Worse, they may internalize native-speaker world view that is embedded in English language education and may marginalize discourses that are scholastically, culturally and linguistically associated with non-native or periphery speakers. Some empirical findings in Thailand as reviewed below illustrate these claims.

Jindapitak and Teo (2012) conducted an investigation into Thai English majors' stereotypical reactions to world Englishes. With the use of the verbal guide test in attitudinal elicitation, it was found that the participants tended to stereotype speakers based on accents. Also reflected is a study conducted by Buripakdi (2012b) to investigate Thai professional writers' positions towards the notion of Thai English, it was revealed 
that these writers marginalized themselves in relation to the native-speaker discourse and Western ideology. They held the belief that everything associated with the West was more standardized, advanced and sophisticated. Buripakdi (2012b) concluded that the belief of this kind reaffirmed that the writers devalued their own version of English, had low self-esteem, and even marginalized their own discourse. Similarly, Methitham (2009) explored local Thai English teachers' perceptions of ELT and aimed to determine to what extent these perceptions revealed the characteristics of de facto colonialism in local ELT in Thailand. It was found that Thai scholastic values were perceived as inferior to those of the English-speaking West. Regarding linguistic and cultural dimension, the teacher participants believed that Thai students will learn English better if they conform to the linguistic and cultural norms of native speakers. Moreover, it was also found that native speakers were given more job opportunities in the local ELT in Thailand.

Given the changing architecture of English as a lingua franca in the global context, how do young folks, especially future English users, think about this? Do they still hold the belief that the notion of standard English should be defined on the basis of native-speaker linguistic expertise? These questions generate my interest in exploring how Thai tertiary English learners perceive the notion of standard English in the era where English becomes Englishes. In order to make English language education more relevant to local contexts in which English is used, I maintain that pedagogical choices or norms should not be constrained by ideological conditions which are merely based on the "Anglo-Saxon view of the world" (Kubota, 1998, p. 298). These conditions, as Tupas (2006) illustrates, "help prevent teachers from practicing what in theory are sociolinguiatically and politically legitimate ways to deal with English [in local contexts]" (p. 107).

\section{Aims and Research Questions}

In Thailand, even though English is taught and learned as a foreign language and has no official role in the society, due to its significant importance as a world language, Thai students are required to study English as a compulsory language from the elementary level. The rationale for this study is based on the emergence of several new Englishes in the Outer and Expanding Circle and people's increasing needs to use it as a lingua franca. In recent years, most universities in Thailand have placed high emphasis on developing students' linguistic skills in order to get them ready for the rapidly changing world. Convinced by the prevalent assumption of native-speaker linguistic superiority or standard language ideology (Jenkins, 2007), pedagogical orientations in language classroom tend to be extremely centered on the native-speaker norms. In addition, Boriboon (2011) claims that the concept of native-speaker idealization assuming language use has been part of ELT policies in Thailand for decades. These policies have been endorsed by the central government, widely adopted and practiced by ELT practitioners, and finally passed on to language learners to uphold. The standard language ideology can be observed in the core curriculum for basic education as launched by the Ministry of Education in 2008 (Boriboon, 2011). In detail, when talking about language learning goal and development in several academic aspects, the term 'native speaker' is vastly referred to. What is more, it is also advisable that the selection of both linguistic and paralinguistic expressions should conform to customs and social norms of native speakers (Ministry of Education, 2008).

However, since English has become more hybridized, institutionalized or dehegemonized in local contexts as suggested by EIL and world Englishes scholars, the question arises as to whether there is still such belief that non-native speakers from non-native settings should be best served by a single variety of English (Jenkins, 2007). In this study, I intended to investigate Thai tertiary English learners' perceptions of the notion of standard English. Knowing how the learners critically discussed and argued about the notion of standard English may generate a better understanding of whether the construct of idealized native speaker (or known as colonial linguistic ideology) is still deeply entrenched in Thailand, a non-colonized country. This study was guided by the following research questions:

1) How do Thai tertiary English learners construe standard English?

2) What justifications do they employ to support their understandings?

\section{Methodology}

\subsection{Participants}

In this project, five fourth-year English majors from the Faculty of Education, Prince of Songkla University, Thailand were invited for the focus group interview. These students currently enrolled in my English conversation course (elective course). In fact, a total of 29 students of different years (sophomore, junior and senior) and faculties (Humanities and Social Sciences, Communication Sciences, Sciences and Technology and Education) enrolled in my course. However, I decided to recruit only five seniors from the Faculty of Education 
(English major) because of the two main reasons. First, I believed that they were mature enough both academically and intellectually. In fact, this group of students had already passed several major subjects (both required and elective) such as Applied Linguistics and Sociolinguistics prior to this course. Hence, it could be assumed that they had greater world view of the English language than other groups of students. Second, they were considered future users of English. Since all of them were trained to become future English teachers, their insights into the role of English in the world were considered important to the development of ELT in Thailand. These made them interesting subjects of this study.

\subsection{Method}

I employed focus group interview as the major research tool in this study. There were several reasons in which this kind of method was a useful tool in the current study. First, it allowed me to obtain information in a short time. Second, as the nature of this research method involves social interaction among those being interviewed (Krueger, 1994), the participants in this study could listen to others, discuss, question and provide feedback or comments spontaneously. Third, the focus group interview was very low cost and could overcome the problem of time consuming in one-to-one interview as it provided speedy results.

The interview questions were formulated based on the research questions. The participants were asked to critically provide response for the following questions:

1) How can you define the term 'standard English'?

2) Why do you think so?

For ethical reason, All the participants were asked to suggest a pseudonym (English name) for themselves. They preferred to be called (in English) Patrick, Lucie, Anastasia, Diana and Jennifer. The interview lasted for about one hour and was tape-recorded. The interview was conducted in the participants' mother tongue with an explanation of research aims and assurance about anonymity. The participants were encouraged to actively take part in the discussion and to be free to emphasize any points they wished. The interview scripts were translated into English. In this process, two translation experts were consulted for any stylistic difficulties (different wordings) in translation. The translated texts were then sent back to the participants for the purpose of allowing them to review their own scripts and add any additional details they wished (Suwanarak, 2010).

\section{Findings}

All the participants seemed to voice the idea that the concept of standard English refers to varieties of English spoken by native speakers in the Inner Circle. Major native-speaking varieties such as American English, British English, Australian English, Canadian and New Zealander English were variously and broadly referred to by the participants. It is interesting to note that while two informants considered all varieties spoken by native speakers as the standard Englishes, the other three mentioned that only varieties spoken by native speakers in the two countries: America and England were justified as standard. Maintaining that English originated in the West, one of the participants (Patrick) illustrated how the definition of standard English is shaped by the concept of English origin:

"Basically, I think standard English means native-like English or a version of English spoken by native speakers from America, Britain, Canada and Australia, for example. (INTERVIEWER: Why do you think so?) Perhaps, English originated in these countries. So, it is automatically considered as standard. I think it's proper to give credit to those who are the real owners of the language."

Agreeing with Patrick, Lucie additionally mentioned the need to mimic the way native speakers use the language:

"People from these countries speak standard English, the kind of English that we often hear from audio materials in our classroom. I think it's a good idea to mimic how native speakers from these countries use the language because it's the goal of every language learner in the world. If we can use theirs, people out there will think that we are kind of smart, and of course, we will look classy."

As we can see from the above statements, every native speaker, according to Patrick and Lucie is said to speak standard English. However, as a reaction to the previous sayings, Anastasia questioned that not all varieties of inner-circle English are considered standard. She made an observation that:

"I think you made some mistakes. I'm not sure if we can say that all native-speaker varieties can be called 'standard'. According to my knowledge, there're several other small islands in the Caribbean and Australasian sea that use English as a native language. Even in Australia, people there speak with wrong pronunciation. For example, they speak: "How are you to die?" instead of "How are you today?" Can you 
say that people from these countries speak standard English? I don't think so. Their English is so unintelligible and funny."

In agreement with Anastasia, Diana made a claim by taking an example of a Hollywood actress who speaks English with a non-American accent which is unpleasant to listen to. She stated:

"I agree with Anastasia. Not all native speakers speak with an ear-pleasing accent. Even Hollywood movie stars who do not reside in America or England speak non-standard English. I have watched several TV series starred by Ashley Jensen. She has a very thick Scottish accent which is a bit hilarious and unpleasant to me."

Anastasia and Diana seemed to assume that standard English refers only to varieties spoken by people residing in American and England and seemed to marginalize other native varieties such as Australian, Scottish, Caribbean and Australasian accents. Up to this point, I acknowledged them that there are a wide range of accents within America and England, for example, Cockney English — a variety spoken by working class Londoners, or African-American vernacular - a variety spoken by black people in America. I further asked: Are these varieties considered standard as well?

Anastasia suddenly switched her mind and said:

"I totally forgot about this fact. These varieties are actually non-standard. I think the standard ones have to be highly valued by people in the societies. I mean they have to sound right, correct, intelligible, beautiful and high-class. Weird accents like the ones in your examples are excluded."

Jennifer supported Anastasia's opinion and offered an additional idea:

"I just want to add that one way to identify whether a variety is standard is to look at how widespread and popular the language is used or spoken. I mean the more a certain variety is used, the more likely it is to become standardized. (INTERVIEWER: Can you give an example? What variety that shares this characteristic?) The Received Pronunciation (RP) or Queen's English."

So far, while some seemed to be convinced by the last claim that RP or Queen's English is considered as the unrivaled standard English variety mainly because it sounds prestigious and is spoken by the majority of native speakers, others showed some confusion as they pointed out that there were some fallacies behind the belief about the prestige and popularity of RP. Considering the belief that RP is spoken by the majority of people is a fallacy, Patrick critiqued:

"In fact, the majority of people in England do not speak with a pure RP accent. They speak more with other accents. Do you remember what we learned from Sociolinguistics class? Only a small number of the British populations use RP. So, I think it's not appropriate at all to associate the term 'standard' with the variety that is spoken by the minority."

As we came to this point, I encouraged them to discuss in more depth in order to find possible conclusion that was unanimously agreed. Interestingly, Patrick, who had previously thought that every single native variety is called standard, shifted to a new idea based on the assumption that for ones being able to speak standard English requires being educated. He asserted that:

"Standard English means educated English. It's a kind of educated variety verbalized by educated people. You can tell your students to look up to educated people regarding how they academically use the language. It's like when we follow writing convention and styles of well-known writers or those proficient in English. Is this assumption good enough to define standard English?"

Lucie, Diana and Jennifer were strongly against the idea offered by Patrick. They noted that one's English proficiency or education has nothing to do with how standard English is defined. They acknowledged that not all educated people speak good English. One of them (Lucie) argued that:

"Do you mean all educated non-native speakers speak good English? Of course, the answer is no. I think education is not a key factor determining how standard English is defined. (INTERVIEWER: Can you give more details about this?) As you know, many educated Thais, who appear in media, speak poor or incomprehensible English. This is very embarrassing. Since they're non-native speakers, they can't be called standard English users."

Agreeing with Lucie, Diana added that:

"Even top politicians who were educated in native-speaking countries speak broken English. They totally fail. Our society places high hope on those who are highly literate. It's a pity that they have high education 
but speak alien English. This is just to confirm that education is not an indication whether the holder is capable of using standard form of English."

Jennifer resorted to her previous definition of standard English (RP is standard), but this time, she appeared to be less conclusive as she obtained new knowledge from the discussion that RP is not an accent spoken by the majority. She stated:

"In my opinion, RP should still be made standard because my inner thought tells that it is intrinsically a standard form of English, but I can't help thinking that it is spoken by a small number of people in the UK. I don't know what to say next. Is there any alternative?"

After tiresome talk, everyone seemed to realize that it was not easy to come up with proper and universal definitions for standard English. From the interview, it was obvious that all the participants finished their talks with some puzzlement about what is truly meant by standard English. However, everyone appeared to be in agreement with Patrick's closing remark that the notion of standard English is debatable; therefore, linguists should be careful when making judgment about standard English. Patrick put it:

"Well, I don't know what you guys think about this issue, but to my understanding, the issue of standard English is debatable and does not have sensible conclusion so far. What I can learn from this is that linguists should interpret this concept with considerable caution."

I finished the interview by asking them to provide any comments or say how they felt about this focus group interview task. Anastasia commented that:

"This task made me realize that standard English is a very complex issue. I have never made an attempt to question it." Similarly, Lucie voiced that: "It is a simple question but can't easily be answered." Diana even asked me back: "Teacher, can you tell me, is there such thing as standard English?"

\section{Conclusion and Discussion}

It is clearly seen from the focus group interview that nearly all of the participants still held the belief that native speaker is the authority of the language. That is to say, the global role of English was not reflected in their perceptions of standard English. What is more, it is noticeable from the finding that although the participants were gravitated to native speakers when referring to the notion of standard English, they admitted that they were not clear-cut about its working definitions since they were debatable and open to different interpretations.

It can be safely concluded that the construct of native speaker still plays an influential role in determining the concept of standard English even though several scholars in EIL and world Englishes have acknowledged that English has reached its international status in the world. Given that the standard varieties of the Inner Circle community have been unquestionably accepted and promoted as the only pedagogical norms for ELT across Thailand for decades (Methitham, 2011), it is hardly a surprising finding that native speakers are considered as the standard users of English. Indeed, Boriboon (2008) makes an observation that English language education in Thailand, especially in the tertiary level, is exclusively based on western-compiled commercial textbooks. These textbooks present native speakers as being superior to non-native speakers and are flooded with information regarding cultural meanings, lifestyles, customary discourses associated with the inner-circle community and its speakers (Boriboon, 2008). Therefore, the learning of English, as Shin (2004) argues, is translated into the learning of American and Britain. This orientation is thought to be far removed from students' sociocultural backgrounds and linguistic repertoires and barely relates to the students' daily and/or authentic encounters which rest on the paradigm of English as a lingua franca in communication. When students have continuously been exposed to this colonial concept of method (Kumaravadivelu, 2003) in their actual learning and told by teachers that there is an inherently superior variety of English, it is likely that they end up internalizing such native-speaker views of the world or upholding the status quo of native speaker. This colonial linguistic ideology is thought to become eyeglasses through which they typecast other non-native users of English as uncivilized and inferior to the inner-circle speakers (Kubota, 1998).

\section{Implication}

Pedagogically speaking, cook (1999) suggests that ELT should go beyond the construct of native speaker. That is to say, pedagogical purposes and the goal of English language learning and teaching cannot be assumed that, in the end, students will learn and use English primarily to interact with native speakers and integrate into the inner-circle community (Nayar, 2002). In recent decades, English has been increasingly appropriated by non-native speakers in both the Outer and Expanding Circle to suit their own communicative purposes. It should be made clear that the idea of linguistic appropriateness here does not necessarily mean using English in a way that conforms to the phonological, syntactic, semantic or pragmatic standards of the Inner Circle. What is meant 
by 'appropriateness' can also refer to, for example, how non-native speakers learn and use the language in order to celebrate their own national identity or linguistic rights (Seidlhofer, 2001). In this connection, Crystal (2001) expresses what language learning means in the sense of linguistic right: "To have learned a language is immediately to have right in it. You may add to it, modify it, play with it, create in it, ignore bits of it, as you will" (p. 21). In Crystal's words, linguistic mastery does not equate to imitating or mimicking the conventional linguistic norms of the Inner Circle. This is because when it comes to lingua franca communication, speakers are not only required to utter words or articulate sounds intelligible to their interlocutors; they also need to use English to project their own identity or linguistic rights (Jenkins, 2006; Seidlhofer, 2001; Widdowson, 2003). For example, the Singapore ambassador to the United Nations firmly states: "I should hope that when I am speaking abroad my countrymen will have no problem recognizing that I am a Singaporean" (Strevens, 1992, p. 38-39). This illustrates that it is irrational to demand a person to speak in a way that reflects somebody else's identity in order to obtain social acceptance when he or she really needs to use the language to glorify his/her identity. In the inescapably globalized world which is becoming more multicultural, to talk of the idealized native speaker model in linguistic judgments is an attempt to purify or centralize the English language (Canagarajah, 1999a, 1999b). This linguistic orientation, as Kirkpatrick (2007) and Modiano (2009) argue, is totally at variance with how English is actually used in the context of multicultural societies where multilingual people are the norms. In fact, Nayar (2002) acknowledges that the diversification of English has potentially put the role and status of native speaker as "the representative of correct language acts, authentic pragmatics, proper critical thinking, [and] unassailable rules of elegant social behavior in English ..." (p. 466) in to question.

Drawing on the context of ASEAN where Thailand is a member, English is used as a working lingua franca for international communication among 600 million individuals who are from different linguistic and cultural backgrounds. Thus, curricula should focus more on local varieties of English and concentrate on ASEAN or regional discourses (Wilang \& Teo, 2012) so that learners can negotiate the cultures and pragmatic norms pertinent to people in the region rather than those associated with people in the Inner Circle (Kirkpatrick, 2002). Providing similar ground to Kirkpatrick, Cook (1999) maintains that linguistic resources that are exposed to students should reflect their real-life purposes. Elsewhere, Cook further notes that the goal of language education program should be based on the assumption that students will be equipped to use two languages efficiently without losing their own identity, feeling subordinated or becoming "ersatz native speakers" (Cook, 2001, p. 179). To elaborate, in local ELT contexts, teachers and students must question what is and is not relevant to their own regional uses of the language (Wan, 2013). In this sense, the notion of linguistic appropriateness, attainability and adaptation should be set as the pedagogical goal in which language learners can realistically aspire for. According to McKay $(2002$, 2003), the newer paradigm of international language acquisition should focus on the following ELT assumptions that differ from the native-speaker-mimicry concept of language learning: (i) language learners do not need to internalize the norms of the inner-circle speakers; (ii) the ownership of English is granted to whoever uses it; and (iii) the goal of language learning is to enable learners to communicate their voices and project their identity to others. These assumptions guiding ELT practices should be addressed in language classroom.

In classroom, English language learners should be made aware that successful second language (L2) users, as Erling and Barlett (2006) note, speak the language differently from English-as-a-mother-tongue users, but this does not necessarily imply that their language use is considered deficient or non-standard. Teachers should provide opportunities for learners to interact in English with successful international speakers (Matsuda, 2003) and also educate them that several non-native users "innovate in English making full use of their multilingual resources to create their own preferred forms" (Jenkins, 2011, p. 928). This pedagogical task helps the learners reflect that being successful and effective EIL users does not require being native speakers (Matsuda, 2003). It also helps prevent the learners from forming the idea of resistance and holding prejudicial reactions (Jaber \& Hussein, 2011) when they encounter varieties of English that differ from those of the Inner Circle. Moreover, teachers can also encourage their learners to feel free to use their localized versions of English (as long as they are intelligible and comprehensible) without having to worry that these productions will be evaluated vis-à-vis native-speaker benchmark. This is because linguistic assessment in the EIL paradigm does not focus on how closely learners approximate the standards of native speakers, but it realistically concentrates on the learners' communicative effectiveness (Matsuda, 2003) and international intelligibility (Jenkins, 2000). Thus, directing one's energy in the pursuit of native-speaker likeness becomes irrelevant when lingua franca communication is involved. Seidlhofer (2001) supports this claim as she says: "Native-speaker language use is just one kind of reality, and one of very doubtful relevance for lingua franca contexts" (p. 138). Thus, the popularly-claimed assumption in ELT that one variety (assumably a native-speaker dialect) is superior to others is considered a 
linguistic myth (Jenkins, 2007; Lippi-Green, 1997; Medgyes, 1992, 1994). This notion is shaped by the political construct of the language rather than linguistic reality.

Cook (1999) suggests that the ultimate acquisition of L2 learning "should be defined in terms of knowledge of the L2" (p. 191) not in terms of what a native speaker in the Inner Circle knows. Kramsch (1998) illustrates that: "Traditional methodologies based on the native speaker usually define the language learners in terms of what they are not, or at least not yet" (p. 28). Likewise, Cook (1999) asserts that it is fallacious that L2 learners' linguistic competence is often assessed against native-speaker linguistic yardstick. The claim that L2 learners fail to become native speakers in L2 acquisition "is like saying that ducks fail to become swans: Adults could never become native speakers without being reborn" (p. 187). To make ELT more realistic and meaningful in lingua franca contexts, in the end, language learners should come to realize that the notion of standard English should relate to what people know and can professionally do not where they come from (Holliday, 2008, 2009; Rampton, 1995). Given that the notion of standard English is a linguistic myth which is rather based on the element of nation and inherent/intrinsic values ascribed to a language variety (Bezooijen, 2002; Giles et al., 1974; Holliday, 2008) than on linguistic descriptions, "possessing the standard should be EARNED in the sense that it can be learned ..., not born into with any form of 'native' advantage" (Holliday, 2008, p. 129).

\section{References}

Acar, A. (2007). Standard and competence in English as an international language pedagogy. The Asian EFL Journal Quarterly, 9(4), 39-53.

Achebe, C. (1975). Morning yet in creation day. New York: Doubleday.

Bezooijen, R. V. (2002). Aesthetic evaluation of Dutch: Comparison across dialects, accents and languages. In D. Long, \& D. R. Preston (Eds.), Handbook of perceptual dialectology (Vol. 2, pp. 13-30). Amsterdam and Philadelphia: Benjamins.

Boriboon, P. (2008). Cultural voices and representations in EFL materials design, pedagogy, and research. (Unpublished doctoral dissertation), University of Edinburgh, Edinburgh, Scotland.

Boriboon, P. (2011). Language, ideology and domination: Problems of English language teaching in Thailand and solutions. Songklanakarin Journal of Social Sciences and Humanities, 17(6), 23-59.

Buripakdi, A. (2012a). On professional writing: Thai writers' views on their English. International Journal of Applied Linguistics, 22(2), 245-264. http://dx.doi.org/10.1111/j.1473-4192.2012.00311.x

Buripakdi, A. (2012b). The marginalized positions of Thai professional writers on the global hegemony of English. Journal of Asian Pacific Communication, 22(1), 41-59. http://dx.doi.org/10.1075/japc.22.1.03bur

Canagarajah, A. S. (1999a). Interrogating the Native speaker fallacy: Non-linguistic roots, non-pedagogical results. In G. Braine (Ed.), Non-native educators in English language teaching (pp. 77-92). Mahwah, New Jersey: Lawrence Erlbaum Associates.

Canagarajah, A. S. (1999b). Resisting linguistic imperialism in English teaching. Hong Kong: Oxford University Press.

Cook, V. (1999). Going beyond the native speaker in language teaching. TESOL Quarterly, 33(2), 185-209. http://dx.doi.org/10.2307/3587717

Cook, V. (2001). Second language learning and language teaching (3rd ed.). London: Arnold.

Crystal, D. (2000). The future of Englishes. In A. Burns, \& C. Coffin (Eds.), Analysing English in a global context: A reader (pp. 53-64). London and New York: Routledge.

Crystal, D. (2001). Global Understanding for global English. Moscow State University Bulletin, 19(4), 13-28.

Crystal, D. (2003). Final frontiers in applied linguistics. In S. Sarangi, \& T. Van Leeuwen (Eds.), Applied linguistics and communities of practice (pp. 9-24). London: Continuum.

Erling, E. J., \& Barlett, T. (2006). Making English their own: The use of ELF among students of English at the Free University of Berlin. Nordic Journal of English Studies, 5(2), 9-40.

Giles, H., Bourhis, R., Trudgill, P., \& Lewis, A. (1974). The imposed norm hypothesis: A validation. Quarterly Journal of Speech, 60, 405-410. http://dx.doi.org/10.1080/00335637409383249

Holliday, A. (2008). Standards of English and politics of inclusion. Language Teaching, 41(1), 119-130. http://dx.doi.org/10.1017/S0261444807004776

Holliday, A. (2009). English as a lingua franca, 'non-native speakers' and cosmopolitan realities. In F. Sharifian 
(Ed.), English as an international language: Perspectives and pedagogical issues (pp. 21-33). Bristol: Multilingual Matters.

Jaber, M., \& Hussein, R. (2011). Native speakers' perception of non-native English speech. English Language Teaching, 4(4), 77-87. http://dx.doi.org/10.5539/elt.v4n4p77

Jenkins, J. (2000). The phonology of English as an international language. Oxford: Oxford University Press.

Jenkins, J. (2006). Global intelligibility and local diversity: Possibility or paradox? In R. Rubdy, \& M. Saraceni (Eds.), English in the world: Global rules, global roles (pp. 32-39). London: Continuum Press

Jenkins, J. (2007). English as a lingua franca: Attitudes and identity. Oxford: Oxford University Press.

Jenkins, J. (2011). Accommodating (to) ELF in international university. Journal of Pragmatics, 43, $926-936$. http://dx.doi.org/10.1016/j.pragma.2010.05.011

Jindapitak, N., \& Teo, A. (2011). Linguistic and cultural imperialism in English language education in Thailand. Journal of Liberal Arts, Prince of Songkla University, 3(2), 10-29.

Jindapitak, N., \& Teo, A. (2012). Thai Tertiary English Majors Attitudes Towards and Awareness of World Englishes. Journal of English Studies, 7, 74-116.

Kachru, B. B. (1992). The other tongue: English across cultures (2nd ed.). Urbana: University of Illinois Press.

Kirkpatrick, A. (2002). ASEAN and Asian culture models: Implications for the ELT curriculum and for teacher selection. In A. Kirkpatrick (Ed.), Englishes in Asia (pp. 213-224). Melboutne: Language Australia.

Kirkpatrick, A. (2007). World Englishes: Implications for international communication and English language teaching. Cambridge: Cambridge University Press.

Kramsch, C. (1998). The privilege of the intercultural speaker. In M. Byram, \& M. Fleming (Eds.), Language learning in intercultural perspective: Approaches through drama and ethnography (pp. 16-31). Cambridge: Cambridge University Press.

Krueger, R. A. (1994). Focus groups: A practical guide for applied research. Thousand Oaks, CA: Sage.

Kubota, R. (1998). Ideologies of English in Japan. World Englishes, 17(3), $295-306$. http://dx.doi.org/10.1111/1467-971X.00105

Kumaravadivelu, B. (2003). Critical language pedagogy: A postmethod perspective on English language teaching. World Englishes, 22(4), 539-550. http://dx.doi.org/10.1111/j.1467-971X.2003.00317.x

Lippi-Green, R. (1997). English with an accent. London: Routledge.

Matsuda, A. (2003). Incorporating world Englishes in teaching English as an international language. TESOL Quarterly, 37(4), 719-729. http://dx.doi.org/10.2307/3588220

McKay, S. L. (2002). Teaching English as an international language: Rethinking goals and approaches. Oxford: Oxford University Press.

McKay, S. L. (2003). Toward an appropriate EIL pedagogy: Re-examining common ELT assumptions. International Journal of Applied Linguistics, 13(1), 1-22. http://dx.doi.org/10.1111/1473-4192.00035

Medgyes, P. (1992). Native or non-native: Who's worth more? ELT Journal, 46(4), $340-349$. http://dx.doi.org/10.1093/elt/46.4.340

Medgyes, P. (1994). The non-native teacher. London: Macmillan.

Methitham, P. (2009). An exploration of culturally-based assumptions guiding ELT practice in Thailand, a non-colonized country. (Unpublished doctoral dissertation). Indiana University of Pennsylvania, Indiana.

Methitham, P. (2011). English as a modern-day Trojan horse: The political discourses of English language teaching. Journal of Humanities, Naresuan University, 8(1), 13-30.

Ministry of Education. (2008). The basic core curriculum B.E. 2551 (A.D. 2008). Bangkok: The Agricultural Co-operative Federation of Thailand Printing House.

Modiano, M. (2009). EIL, native-speakersim and the failure of European ELT. In F. Sharifian (Ed.), English as an international language: Perspectives and pedagogical issues (pp. 58-77). Bristol: Multilingual Matters.

Nayar, B. (2002). Ideological binarism in the identities of native and non-native English speakers. In A. Duszak (Ed.), Us and them social identities across discourses and cultures (pp. 463-479). Amsterdam/Philadelphia: John Benjamins 
Prodroumou, L. (1997). Global English and the octopus. IATEFL Newsletter, 137, 18-22.

Rampton, B. (1995). Crossing: Language and ethnicity among adolescents. London: Longman.

Seidlhofer, B. (2001). Closing a conceptual gap: The case for a description of English as a lingua franca. International Journal of Applied Linguistics, 11(2), 133-158. http://dx.doi.org/10.1111/1473-4192.00011

Seidlhofer, B. (2006). English as a lingua franca in the Expanding circle: What it isn't. In R. Rubdy, \& M. Saraceni (Eds.), English in the world: Global rules, global roles (pp. 40-50). London: Continuum Press.

Shin, J. K. (2004). The use of Freirian pedagogy in teaching English as an international language: Raising the critical consciousness of EFL teachers in Korea. LLC Review, 4(1), 64-82.

Strevens, P. (1992). English as an international language: Directions in the 1990s. In B. B. Kachru (Ed.), The other tongue: English across cultures (2nd ed., pp. 27-47). Urbana: University of Illinois Press.

Suwanarak, K. (2010). Can only native English speaking teachers teach aural and oral skills? ABAC Journal, 30(2), 43-63.

Tupas, T. R. F. (2006). Standard Englishes, pedagogical paradigms and their conditions of (im)possibility. In R. Rubdy, \& M. Saraceni (Eds.), English in the world: Global rules, global roles (pp. 169-185). London: Continuum Press.

Wan, J. (2013). Localization of the English public speaking course in China's EFL curriculum. Asian Social Science, 9(1), 94-104. http://dx.doi.org/10.5539/ass.v9n1p94

Widdowson, H. G. (1994). The ownership of English. TESOL Quarterly, 28(2), 337-389. http://dx.doi.org/10.2307/3587438

Widdowson, H. G. (1997). EIL, ESL, EIL: Global issues and local interests. World Englishes, 16(1), 135-146. http://dx.doi.org/10.1111/1467-971X.00054

Widdowson, H. G. (1998). EIL: Squaring the circles: A reply. World Englishes, 17(3), 397-404. http://dx.doi.org/10.1111/1467-971X.00113

Widdowson, H. G. (2003). Defining issues in English language teaching. Oxford: Oxford University Press.

Wilang, J. D., \& Teo, A. (2012). Exploring the relationship between intelligibility and education. International Journal of Linguistics, 4(4), 104-115. http://dx.doi.org/10.5296/ijl.v4i4.2315 